\title{
Ectomycorrhizae of Norway spruce from its southernmost natural distribution range in Serbia
}

\author{
Marina Katanić (1), \\ Saša Orlović (1), \\ Tine Grebenc ${ }^{(2)}$, \\ Marko Bajc (2), \\ Saša Pekeč ${ }^{(1)}$, \\ Milan Drekić (1), \\ Hojka Kraigher ${ }^{(2)}$
}

\begin{abstract}
Norway spruce (Picea abies Karst.) reaches its southernmost limit in the mountainous regions of south Serbia and Bulgaria. The species is a regionally important timber species for the wood industry and a significant host for various ectomycorrhizal fungi, including edible species. We analysed ectomycorrhizal community and fine root parameters of high continental / subalpine Norway spruce stands at three sites (Stara planina, Kopaonik, Tara) located in protected areas in Serbia. In addition, we assessed the potential effects of altitude and growing season on the ectomycorrhizal diversity and fine root parameters. Using standardised sampling in combination with morpho-anatomical and molecular identification of ectomycorrhizae, we recorded 29 different anatomorphotypes. None of the identified fungi belonged to commercial edible fungal species. Compared to other Norway spruce ectomycorrhiza studies in central Europe, sites in Serbia exhibited lower species diversity and different dominant species composition, with Cenococcum spp. and Russula spp. as the dominant ectomycorrhizal fungi. A number of ectomycorrhizal types and the value of the species richness index differed between Stara planina and Tara in the autumn, but the influence of site and season on the studied diversity indices was not significant. The total number of fine roots increased in the spring, while percentage of vital ectomycorrhizal root tips increased in the autumn. This study was the first examination of Norway spruce ectomycorrhizal communities at the edge of the natural geographical range of the species.
\end{abstract}

Keywords: Ectomycorrhiza, Picea abies Karst., Community Structure, Diversity, Fine Roots

on high mountains and mountain ranges with cold and humid climate or in frost sinkholes (Jovanović 1991, Ballian et al. 2007). The local populations are likely to be relicts from the last glaciation period (Lewandowski et al. 1997, Ravazzi 2002).

Besides its importance as a quality wood source, Norway spruce is known to host several ectomycorrhizal species (Agerer \& Rambold 2017) that are renowned for their culinary value, for example Boletus edulis Bull., Cantharellus cibarius Fr. and Hydnum rufescens Pers. These and other ectomycorrhizal fungi are commonly collected by locals and either consumed or sold at regional markets (Boa 2004).

Norway spruce forests of Europe have
(1) University of Novi Sad, Institute of Lowland Forestry and Environment, Antona Cehova 13, 21000 Novi Sad (Serbia); (2) Slovenian Forestry Institute, Večna pot 2, 1000 Ljubljana (Slovenia)

@ Marina Katanić (katanicm@uns.ac.rs)

Received: Jan 18, 2018 - Accepted: Oct 26, 2018

Citation: Katanić M, Orlović S, Grebenc T, Bajc M, Pekeč S, Drekić M, Kraigher H (2019). Ectomycorrhizae of Norway spruce from its southernmost natural distribution range in Serbia. iForest 12: 43-50. - doi: 10.3832/ifor2729-011 [online 2019-01-10]

Communicated by: Alberto Santini been thoroughly studied for ectomycorrhizal diversity (Taylor et al. 2000). Ectomycorrhizal communities in Norway spruce populations were well studied from the Central and Southern Alps, namely Slovenia (Kraigher 1999), Austria (Wang et al. 2015) and Germany (Baier et al. 2006), as well as in the Carpathian mountains for Central European populations (Peter et al. 2008) and the Northern populations in the boreal region (Dahlberg et al. 1997, Ostonen et al. 2011, Ostonen et al. 2013).

The isolated populations of Norway spruce on mountains in Serbia remain unexplored for their ectomycorrhizal community. To bridge this knowledge gap, we selected sites at three protected areas at mountains where spruce reaches its southernmost distribution range: Stara planina, Kopaonik and Tara, located in Southeast, South and Southwest Serbia, respectively. The study focused on the diversity of ectomycorrhizal fungi at Norway spruce natural sites and on potential influences of two contrasting seasons (spring and autumn) and three different sites on ectomycorrhizal communities of spruce.

\section{Methodology}

Sites and sampling procedures

The sampling sites were selected in spruce stands located in protected areas in 
Serbia. Sites were selected aiming at covering the distribution patches of spruce at its southernmost natural distribution range on mountains in Serbia (Skrøppa 2003). Detailed characteristics of the selected areas are provided in Tab. 1.

Soil sampling (four per site) was performed in the absence of snow cover, in September 2013 and June 2014, resulting in eight samples per site. A standardised soil corer with $4-\mathrm{cm}$ diameter and $18-\mathrm{cm}$ length (total volume $274 \mathrm{ml}$ ) was used for soil core sampling at $0.5 \mathrm{~m}$ from the tree trunks (Kraigher 1999). At mixed sites, the areas with pure Norway spruce were targeted for sampling. When possible, soil cores were taken from locations with trees of different age to obtain potentially wider diversity of ectomycorrhizal community.

Soil samples were stored at $4{ }^{\circ} \mathrm{C}$ for up to 6 weeks. Prior to analyses, each sample was submerged in cold tap water to loosen the soil structure. All roots were carefully washed from soil. Using a binocular (Kruss $\mathrm{GmbH}$, Hamburg, Germany) with magnifications 10-45× (light source: Olympus Highlight 3100, daylight filter), fine roots were separated into vital ectomycorrhizal root tips, old and non-turgescent fine roots, or non-mycorrhizal vital fine roots.

The ectomycorrhizal species were identified in a two-step procedure combining morphological and anatomical characterisation of ectomycorrhizal root tips to a level of an individual anatomorphotype. Each anatomorphotype was further analysed by molecular analysis of nuclear rDNA ITS region.

Microscopic characteristics of ectomycorrhizal root tips were assessed using an Olympus BX $51^{\oplus}$ (Olympus Corp., Tokyo Japan) with magnifications 100-2000x. Anatomorphotypes of ectomycorrhiza were identified by comparison with published descriptions in Agerer et al. (2006), Agerer (2008), or Agerer \& Rambold (2017), fol- lowing the methodology given by Agerer (1991) and Kraigher (1996).

Ectomycorrhizal types were also classified into the exploration types based on the presence and abundance of emanating elements as proposed by Agerer (2001). All vital ectomycorrhizal root tips, old and non-turgescent fine roots and non-mycorrhizal vital fine roots were counted under a binocular. Total number of fine roots was obtained by summing all of these categories of roots.

Coarse roots in each soil sample were checked for tree roots species confirmation following the anatomical characteristics of wooden parts (Mrak et al. 2016). All extraneous coarse roots with attached fine roots were eliminated from further analysis.

\section{Molecular identification of}

\section{ectomycorrhizal fungi}

Molecular confirmation of fungal partners in ectomycorrhiza using molecular methods was based on a PCR amplification of fungal nuclear rDNA ITS region from each separated anatomorphotype. This molecular marker is currently considered as the best for fungi barcoding and differentiation at the species level (Kõljalg et al. 2013). Total genomic DNA was extracted from ethanol-stored ectomycorrhizal root tips using a Plant DNeasy ${ }^{\circledR}$ Mini Kit (Qiagen, Hilden, Germany). If DNA extraction of representative ectomycorrhizal root tips of some anatomorphotype was not successful and morpho-anatomical identification was insufficient to determine the ectomycorrhizal fungus, this ectomycorrhizal type remained unidentified and was labelled as "unknown" type.

Amplifications were performed with ITS If (Gardes \& Bruns 1993) and ITS 4 primer pair (White et al. 1990). PCR reactions were optimized for the quantity of DNA extract and annealing temperature to give the best product in the reaction. Amplification reaction was performed in GeneAmp ${ }^{\circledast} \mathrm{PCR}$ System 9700 (Applied Biosystems, Foster City, CA, USA) according to the procedure explained by Sulzbacher et al. (2016). Negative controls with no fungal DNA were run for each experiment to check for any contamination. The PCR mixture for one sample was composed of $5 \mu \mathrm{l}$ of $10 \times$ Gold Buffer, $4 \mu \mathrm{l}$ of deoxynucleotide triphosphates ( $0.2 \mathrm{mM}$ each), $1.2 \mu \mathrm{l}$ of each primer ( 0.32 $\mu \mathrm{M}$ each), $4 \mu \mathrm{l}$ of $\mathrm{MgCl}_{2}(2.0 \mathrm{mM}), 30.3 \mu \mathrm{l}$ of sterile distilled water, $0.3 \mu \mathrm{l}$ of Taq polymerase $\left(0.03 U \mathrm{Ul}^{-1}\right)$, and $4 \mu \mathrm{l}$ of DNA extract. Thermal cycling conditions were as follows: initial denaturation and polymerase activation at $95^{\circ} \mathrm{C}$ for $5 \mathrm{~min} ; 13$ cycles at $94{ }^{\circ} \mathrm{C}$ for $45 \mathrm{sec}, 55^{\circ} \mathrm{C}$ for $55 \mathrm{sec}$ and $72{ }^{\circ} \mathrm{C}$ for $45 \mathrm{sec}$; 13 cycles at $94{ }^{\circ} \mathrm{C}$ for $45 \mathrm{sec}, 55$ ${ }^{\circ} \mathrm{C}$ for $55 \mathrm{sec}$ and $72{ }^{\circ} \mathrm{C}$ for 120 sec; 12 cycles at $94{ }^{\circ} \mathrm{C}$ for $45 \mathrm{sec}, 55^{\circ} \mathrm{C}$ for $55 \mathrm{sec}$ and $72{ }^{\circ} \mathrm{C}$ for $180 \mathrm{sec}$ and a final extension at $72{ }^{\circ} \mathrm{C}$ for $10 \mathrm{~min}$.

Amplified DNA was separated and analysed as described by Grebenc et al. (2009). Amplified DNA fragments were separated and purified from the agarose gel using the Wizard SV ${ }^{\circledast}$ Gel and PCR Clean-Up System ${ }^{\circledast}$ (Promega Corporation, Madison, WI, USA) and sent for Sanger sequencing to Macrogen Korea (Seoul, Korea). Sequencher ${ }^{\oplus}$ ver. 5.1 (Gene Codes Corporations, Ann Arbor, MI, USA) was used to identify the consensus sequence from the two strands of each isolate. Species, genus, or family of ectomycorrhizal fungi were determined by comparing the sequences to those deposited in GenBank (NCBI 2017) and UNITE (Grebenc et al. 2009) databases.

\section{Data analysis}

To compare diversity at sample, site, and season level, Species richness (d), Shannon Weaver diversity index $(\mathrm{H})$, Evenness (e) and Equitability $(J)$ were calculated following Atlas \& Bartha (1981), while the Berger-

Tab. 1 - Coordinates of sites, altitude, climate, mean annual temperature and precipitation (RSHS 2017), soil type (Z. Galić, personal communication), mean temperature in June 2014 and September 2013 (Z. Galić, personal communication) and tree species composition at Stara planina, Kopaonik and Tara sites. $\left({ }^{*}\right)$ : mean annual temperature and precipitation data shown for nearest measuring station in Dimitrovgrad and Zlatibor for Stara planina and Tara, respectively.

\begin{tabular}{|c|c|c|c|}
\hline Site & Stara planina & Kopaonik & Tara \\
\hline Coordinates & $\begin{array}{l}43^{\circ} 10^{\prime} 34.6^{\prime \prime} \mathrm{N} \\
22^{\circ} 43^{\prime} 25.0^{\prime \prime} \mathrm{E}\end{array}$ & $\begin{array}{l}43^{\circ} 18^{\prime} 16.8^{\prime \prime} \mathrm{N} \\
20^{\circ} 50^{\prime} 54.3^{\prime \prime} \mathrm{E}\end{array}$ & $\begin{array}{l}43^{\circ} 55^{\prime} 03.8^{\prime \prime} \mathrm{N} \\
19^{\circ} 25^{\prime} 51.6^{\prime \prime} \mathrm{E}\end{array}$ \\
\hline Altitude (m a.s.l.) & 950 & 1490 & 1060 \\
\hline Climate & $\begin{array}{l}\text { Temperately continental } \\
\text { submontanum, montanum }\end{array}$ & $\begin{array}{l}\text { Temperately continental } \\
\text { montanum, subalpine }\end{array}$ & $\begin{array}{l}\text { Temperately continental } \\
\text { montanum }\end{array}$ \\
\hline Mean annual temperature $\left({ }^{\circ} \mathrm{C}\right)$ * & 10.0 & 3.6 & 7.7 \\
\hline $\begin{array}{l}\text { Mean temperature in June } 2014 \\
\left({ }^{\circ} \mathrm{C}\right)\end{array}$ & 14.5 & 11.0 & 12.6 \\
\hline $\begin{array}{l}\text { Mean temperature in September } \\
2013\left({ }^{\circ} \mathrm{C}\right)\end{array}$ & 12.8 & 9.1 & 9.3 \\
\hline Mean annual precipitation $(\mathrm{mm})$ & 624.7 & 984.4 & 1017.3 \\
\hline Soil type & Brown soil & Ranker & Brown soil \\
\hline Species & $\begin{array}{l}\text { Natural forest of Fagus sylvatica, } \\
\text { Picea abies and Abies alba } \\
\text { spontaneously occuring in minor parts }\end{array}$ & $\begin{array}{l}\text { Natural Picea abies forest } \\
\text { without regeneration }\end{array}$ & $\begin{array}{l}\text { Natural mixed forest of Fagus } \\
\text { sylvatica, Picea abies and Abies } \\
\text { alba with regeneration }\end{array}$ \\
\hline Age of spruce trees (years) & $10-20$ & $50-70$ & $40-50$ \\
\hline
\end{tabular}


Fig. 1 - Relative abundance of ectomycorrhizal types at examined sites Stara planina, Kopaonik, and Tara in the spring and autumn.
Spring

Stara planina

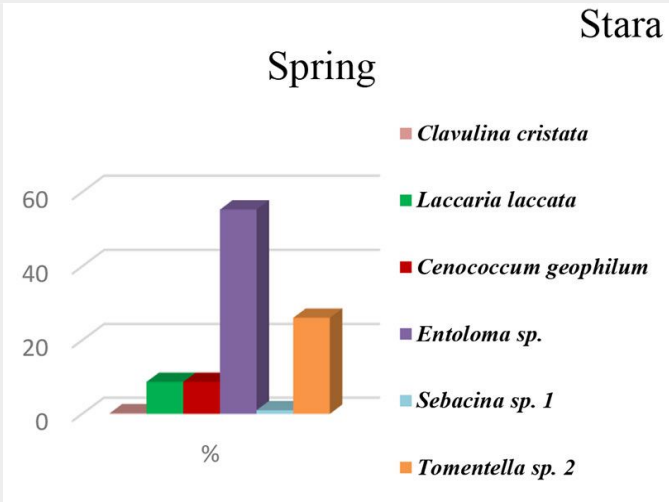

Autumn

Laccaria laccata

- Cenococcum geophilum

- Entoloma sp.

- Inocybe sp. 1

Inocybe sp. 2

- Sebacina sp. 1

Sebacina sp. 2

- Tomentella sp. 2

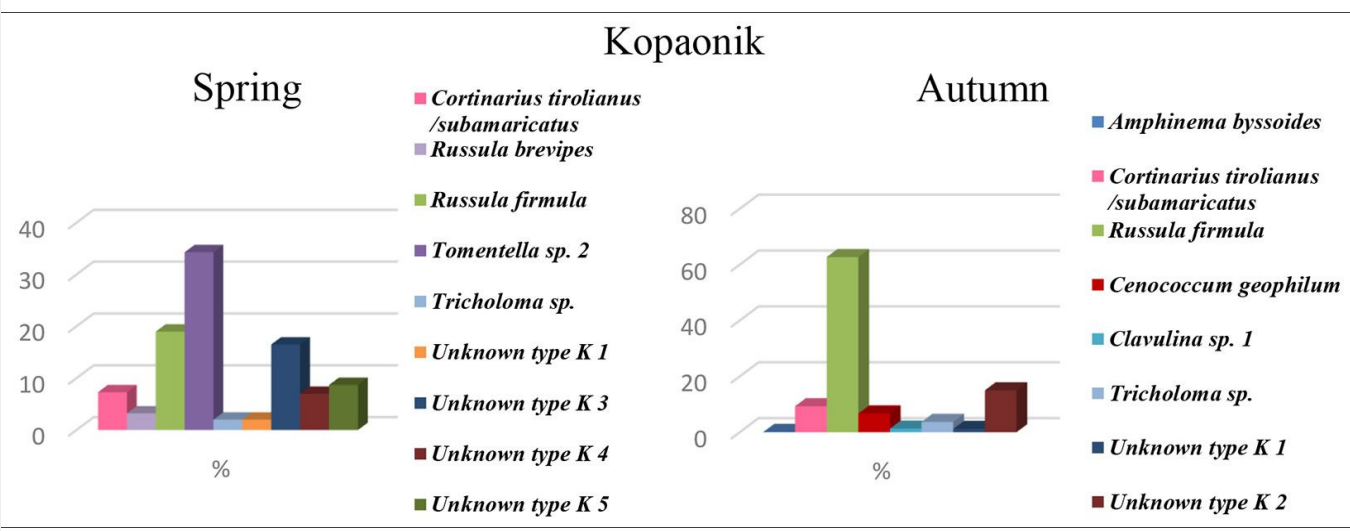

Tara

Spring

Autumn
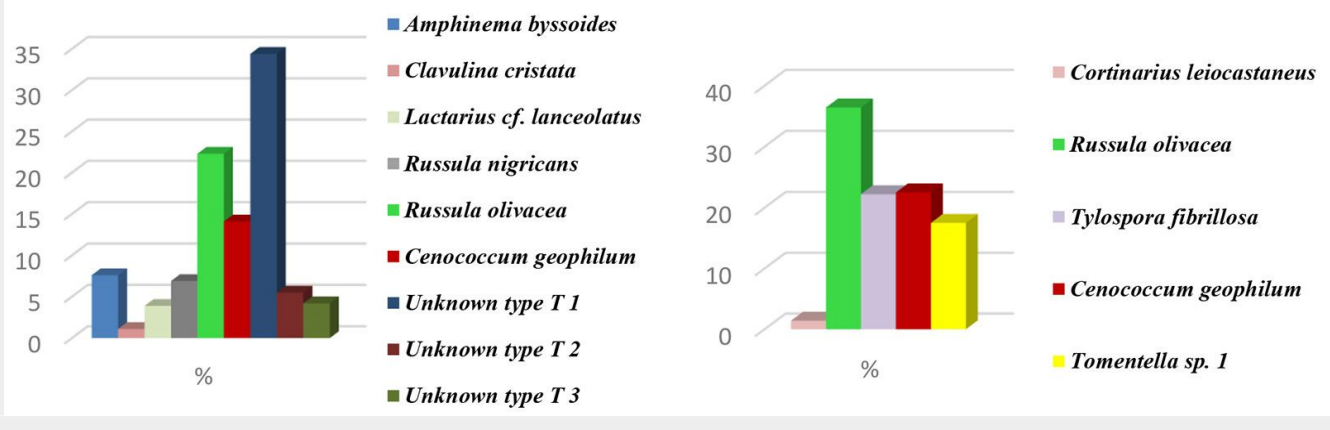

Parker evenness index (BP) was calculated according to Taylor et al. (2000).

Data of an individual soil sample was used as statistical unit. The two-way ANOVA and Fisher's LSD test were used to analyse seasonal and site differences for the measured parameters. In order to obtain normal distribution of data sets for these tests, square root transformation was performed (Bartlett 1936). For a number of ectomycorrhizal types, vital ectomycorrhizal root tips, and total fine roots, arcsine transformation was performed using the Bliss formula (Snedecor \& Cochran 1976) for the percentage of vital root tips. Statistical analyses were performed using the software package STATISTICA ${ }^{\circledR}$ ver. 12.0 (StatSoft, Tulsa, OK, USA).

\section{Results}

Overall, we found 29 different types of ectomycorrhizae at the three selected sites, i.e., 9 at Stara planina, 13 at Kopaonik, and 12 at Tara (Fig. 1). Six ectomycorrhizal types were characteristic for Stara planina, Stara planina and Tara (Fig. 1). Entoloma sp. 9 for Tara and 10 for Kopaonik. Only the ec- and Tomentella sp. 2 were abundantly prestomycorrhizal type determined as Cenococ- ent at Stara planina in the spring, while in cum geophilum was found in all the three the autumn Laccaria laccata, Entoloma sp. examined sites. Tomentella sp. 2 was com- and Tomentella sp. 2 dominated. Ectomycmon at Stara planina and Kopaonik, while orrhizal community from Kopaonik had ToAmphinema byssoides was common at Ko- mentella sp. 2 and Russula firmula as the paonik and Tara, and Clavulina cristata at major constituents in the spring, while the

Tab. 2 - Summarised values for total number of ectomycorrhizal types, vital ectomycorrhizal root tips, total number of fine roots, and percentage of vital ectomycorrhizal root tips on spruce from different sites in Serbia in two examined seasons (based on 4 soil cores per site and per season).

\begin{tabular}{lrrrrrr}
\hline \multirow{2}{*}{ Variable } & Stara planina & Kopaonik & & Tara \\
\cline { 2 - 7 } & spring & autumn & spring & autumn & spring & autumn \\
\hline $\begin{array}{l}\text { Total number of ectomycorrhizal } \\
\text { types }\end{array}$ & 6 & 8 & 9 & 8 & 9 & 5 \\
$\begin{array}{l}\text { Total number of vital } \\
\text { ectomycorrhizal root tips }\end{array}$ & 2060 & 1273 & 1463 & 1469 & 893 & 735 \\
\hline Total number of fine roots & 28175 & 4239 & 5274 & 3174 & 4347 & 2683 \\
\hline \% of vital ectomycorrhizal root tips & 8 & 32 & 28 & 46 & 41 & 27 \\
\hline
\end{tabular}


Tab. 3 - Mean number of ectomycorrhizal (ECM) types, vital ECM root tips, total number of fine roots, percentage of vital ECM root tips, and diversity indices on spruce from different sites in Serbia in the spring and autumn, based on 4 soil samples. Differences among values of a particular variable marked with the same letter are not significant $(p>0.05)$, according to Fisher's LSD test.

\begin{tabular}{|c|c|c|c|c|c|c|c|c|c|c|c|}
\hline \multirow{3}{*}{ Variable } & \multicolumn{6}{|c|}{ Sites by Season } & \multicolumn{3}{|l|}{ Sites } & \multicolumn{2}{|l|}{ Seasons } \\
\hline & \multicolumn{2}{|c|}{ Stara planina } & \multicolumn{2}{|l|}{ Kopaonik } & \multicolumn{2}{|l|}{ Tara } & \multirow{2}{*}{$\begin{array}{l}\text { Stara } \\
\text { planina }\end{array}$} & \multirow{2}{*}{ Kopaonik } & \multirow{2}{*}{ Tara } & \multirow{2}{*}{ Spring } & \multirow{2}{*}{ Autumn } \\
\hline & spring & autumn & spring & autumn & spring & autumn & & & & & \\
\hline Mean number of ECM types & $3.5^{\mathrm{ab}}$ & $4.75^{b}$ & $3.75^{\mathrm{ab}}$ & $3.00^{a b}$ & $3.25^{\mathrm{ab}}$ & $2.5^{a}$ & $4.12^{a}$ & $3.37^{\mathrm{a}}$ & $2.87^{\mathrm{a}}$ & $3.50^{\mathrm{a}}$ & $3.42^{\mathrm{a}}$ \\
\hline Number of vital ECM root tips & $515^{a}$ & $318.7^{\mathrm{a}}$ & $365.7^{\mathrm{a}}$ & $369.7^{\mathrm{a}}$ & $223.2^{a}$ & $226.5^{a}$ & $416.8^{a}$ & $367.7^{\mathrm{a}}$ & $224.8^{a}$ & $367.9^{a}$ & $304.9^{a}$ \\
\hline Total number of fine roots & $7043.7^{b}$ & $1547^{\mathrm{a}}$ & $1327^{a}$ & $806.5^{a}$ & $1186.7^{\mathrm{a}}$ & $671.7^{\mathrm{a}}$ & $4295.3^{b}$ & $1066.7^{a}$ & $929.2^{a} 3$ & $3185.8^{b}$ & $1008.4^{\mathrm{a}}$ \\
\hline$\%$ of vital ECM root tips & $8.7^{\mathrm{a}}$ & $27.2^{\text {ab }}$ & $29.4^{\mathrm{ab}}$ & $45.8^{b}$ & $23.0^{\mathrm{b}}$ & $36.1^{\mathrm{b}}$ & $17.9^{a}$ & $37.5^{b}$ & $29.5^{a b}$ & $20.4^{\mathrm{a}}$ & $36.3^{b}$ \\
\hline Species richness index (d) & $0.925^{a b}$ & $1.507^{b}$ & $1.087^{a b}$ & $0.826^{a b}$ & $0.950 \mathrm{ab}$ & $0.629^{a}$ & $1.216^{\mathrm{a}}$ & $0.955^{a}$ & $0.785^{a}$ & $0.988^{a}$ & $0.982^{\mathrm{a}}$ \\
\hline Shanon Weaver index $(\mathrm{H})$ & $0.736^{a}$ & $1.216^{\mathrm{a}}$ & $1.024^{\mathrm{a}}$ & $0.649^{a}$ & $0.872^{\mathrm{a}}$ & $0.581^{\mathrm{a}}$ & $0.976^{a}$ & $0.835^{a}$ & $0.725^{a}$ & $0.875^{a}$ & $0.815^{\mathrm{a}}$ \\
\hline Evenness (e) & $1.158^{\mathrm{a}}$ & $1.748^{\mathrm{a}}$ & $1.843^{a}$ & $1.239^{\mathrm{a}}$ & $1.695^{\mathrm{a}}$ & $1.007^{\mathrm{a}}$ & $1.453^{\mathrm{a}}$ & $1.540^{\mathrm{a}}$ & $1.350^{\mathrm{a}}$ & $1.563^{a}$ & $1.333^{\mathrm{a}}$ \\
\hline Equitability (J) & $0.503^{a}$ & $0.756^{a}$ & $0.800^{a}$ & $0.538^{a}$ & $0.736^{a}$ & $0.437^{\mathrm{a}}$ & $0.630^{\mathrm{a}}$ & $0.670^{\mathrm{a}}$ & $0.590^{a}$ & $0.681^{a}$ & $0.579^{a}$ \\
\hline Berger-Parker index & $0.319^{a}$ & $0.544^{\mathrm{a}}$ & $0.413^{a}$ & $0.270^{\mathrm{a}}$ & $0.417^{\mathrm{a}}$ & $0.309^{a}$ & $0.432^{\mathrm{a}}$ & $0.340^{\mathrm{a}}$ & $0.364^{\mathrm{a}}$ & $0.382^{a}$ & $0.375^{\mathrm{a}}$ \\
\hline
\end{tabular}

Tab. 4 - F-test of two-way ANOVA for number of ectomycorrhizal types, vital ectomycorrhizal root tips, total number of fine roots, and percentage of vital ectomycorrhizal root tips. (*): $p<0.05$

\begin{tabular}{lccc}
\hline \multirow{2}{*}{ Variable } & \multicolumn{3}{c}{ Factors } \\
\cline { 2 - 4 } & Sites (A) & Seasons (B) & $\begin{array}{c}\text { Interaction } \\
(\mathbf{A} \times \mathbf{B})\end{array}$ \\
\hline Mean number of ectomycorrhizal types & 1.417 & 0.050 & 1.262 \\
Number of vital ectomycorrhizal root tips & 1.428 & 0.385 & 0.320 \\
Total number of fine roots & $16.891^{*}$ & $16.600^{*}$ & $6.348^{*}$ \\
\% of vital ECM root tips & $3.616^{*}$ & $6.485^{*}$ & 0.156 \\
\hline
\end{tabular}

$$
\begin{array}{r}
\text { Fig. } 2 \text { - Mean } \\
\text { abundance of } \\
\text { exploration } \\
\text { types (ET) at } \\
\text { examined } \\
\text { sites Stara } \\
\text { planina (top), } \\
\text { Kopaonik } \\
\text { (middle) and } \\
\text { Tara (bottom) } \\
\text { in the spring } \\
\text { and autumn. }
\end{array}
$$

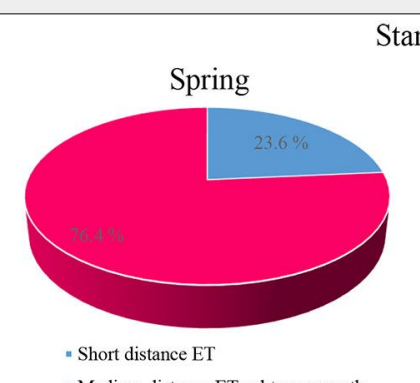

- Medium distance ET subtype smooth

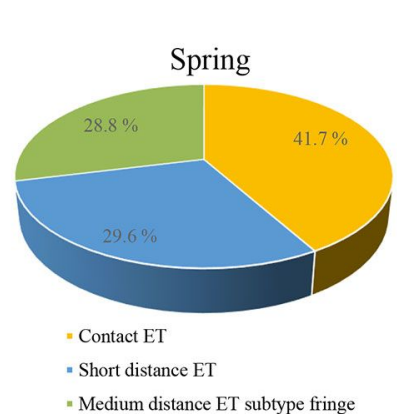

" Medium distance ET subtype fringe Spring

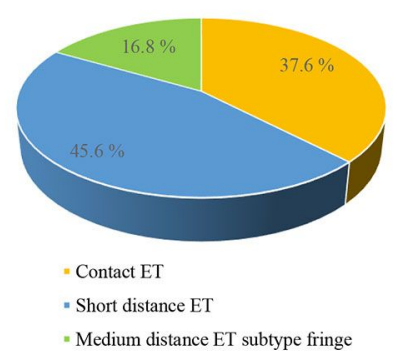

Stara planina

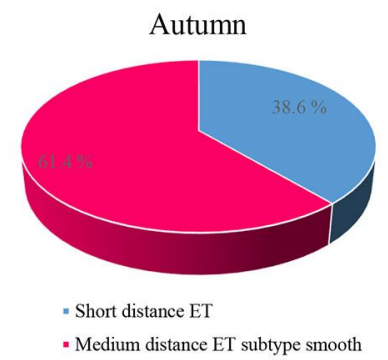

Kopaonik

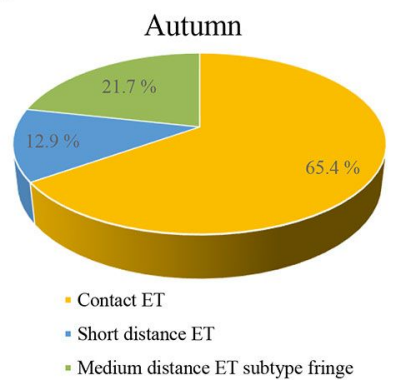

Tara

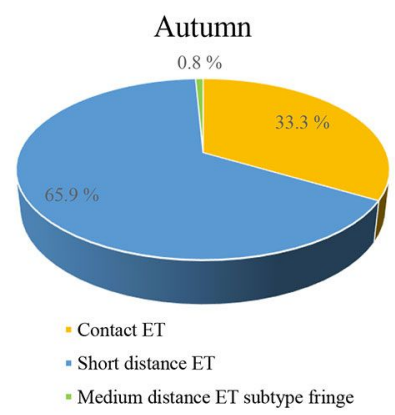

latter made up about $60 \%$ of all ectomycorrhizal root tips in the autumn. Tara in the spring was dominated by Unknown type T1 and Russula olivacea, while in the autumn the most abundant were Russula olivacea, Cenococcum sp. and Tylospora fibrillosa. Only 11 types of ectomycorrhizae were recorded at the studied sites (Stara planina 5, Kopaonik 4 and Tara 2) in both seasons (Fig. 1).

The lowest total number of ectomycorrhizal types was recorded for Tara in the autumn (5), while the highest number (9) was recorded in the spring for the same site and for Kopaonik. The lowest number of vital ectomycorrhizal root tips per site was counted for Tara in the autumn (735), while the highest number was counted for Stara planina in the spring (2060). Also, the highest total number of fine roots and the lowest percentage of vital ectomycorrhizal root tips ( $8 \%$ ) were counted at Stara planina in the spring. On the other hand, the highest percentage of vital ectomycorrhizal root tips was recorded for Kopaonik in the autumn ( $46 \%$ - Tab. 2$)$.

Mean number of ectomycorrhizal types per soil sample was significantly higher for Stara planina in the autumn (4.75) compared with Tara in the same season (2.5 Tab. 3). Number of vital ectomycorrhizal root tips did not significantly differ between seasons and among sites. Samples from Stara planina in the spring had the highest total number of fine roots and the lowest percentage of vital ectomycorrhizal roots compared to that from other sites. Value of Species richness index significantly differed between Stara planina and Tara in the autumn (1.507 vs. 0.629, respectively), but other diversity indices were not significantly different between seasons nor among sites (Tab. 3). Effects of site and season were significant for total number of fine roots and percentage of vital ectomycorrhizal root tips, while the site $\times$ season interaction was significant only for total number of fine roots (Tab. 4).

Presence and abundance of exploration types (ET) differed among the investigated 
spruce stands. Stara planina was dominated by a medium distance exploration type (subtype smooth) with abundance that decreased in the autumn compared to the spring. On the other hand, a number of short distance exploration types increased from the spring to the autumn (Fig. 2a). At Kopaonik the contact exploration type was the most abundant ET in both seasons but its number increased in the autumn while the abundance of the other ET types (short distance ET and medium distance ET fringe subtype) decreased relative to the spring. (Fig. 2b). At Tara, the short distance exploration type was the most numerous $\mathrm{ET}$ in both seasons and its abundance increased in the autumn. Abundance of contact ET was similar in the studied seasons while the number of medium distance ET (subtype fringe) decreased in the autumn compared to the spring (Fig. 2C).

Abundance of contact ET and medium distance ET (both smooth and fringe subtypes) were significantly influenced by site, while the season had no significant impact (Tab. 5).

\section{Discussion}

This insight into the ectomycorrhizal diversity and fine root parameters in Serbia is the first example of a Norway spruce ectomycorrhizal community study from the southernmost edge of the species' range. Although all sites were located in protected, unpolluted areas on mountains, the examined ectomycorrhizal communities differed substantially in their structure and abundance of ectomycorrhizal types.

In general, the most widespread ectomycorrhizal symbiont in the southernmost natural distribution of Norway spruce was Cenococcum geophilum (Ascomycota), likely the most widespread ectomycorrhizal species worldwide (Fernandez et al. 2013). Although several ectomycorrhizal root tips were sampled from this anatomorphotype, only one type (from Stara planina sampled in the autumn) was successfully DNA-analysed and determined to the genus level. All other ectomycorrhizal tips were identified as Cenococcum geophilum according to their easily distinguishable morphological and anatomical characteristics. C. geophilum was the most frequent ectomycorrhizal type which was found at all studied sites. In the Barbarian Limestone Alps (1050 m a.s.l.) Baier et al. (2006) also found Cenococcum geophilum $\mathrm{Fr}$. (with a proportion of $25 \%$ ) as the dominant species in spruce stands. It was known that Cenococcum geophilum and Sebacina spp. successfully cope with high humus contents and large $\mathrm{C}: \mathrm{N}$ ratios (Baier et al. 2006), while C. geophilum prefers organic layers enriched with organic compounds. The frequent occurrence of $C$. geophilum in the studied spruce stands can be explained with the high humus content of soil at these sites.

Tomenteloid fungi are also known to be frequent and widespread ectomycorrhizal partners of deciduous and evergreen tree
Tab. 5 - F-test of two-way ANOVA for exploration types (ET). (*): $p<0.05$.

\begin{tabular}{lccc}
\hline \multirow{2}{*}{ Variable } & \multicolumn{3}{c}{ Factors } \\
\cline { 2 - 4 } & Sites (A) & Seasons (B) & $\begin{array}{c}\text { Interaction } \\
(\mathbf{A} \times \mathrm{B})\end{array}$ \\
\hline Contact ET & $8.175^{*}$ & 0.213 & 0.35 \\
Short distance ET & 2.205 & 0.184 & 0.455 \\
Medium distance ET-subtype fringe & $9.203^{*}$ & 2.374 & 0.966 \\
Medium distance ET-subtype smooth & $67.757^{*}$ & 0.539 & 0.539 \\
\hline
\end{tabular}

species in the forests of Europe and North America (Gardes \& Bruns 1996, Dahlberg 2001). In presented study, this group of fungi was represented by at least one tomenteloid ectomycorrhizal type at every site which was always among the most abundant ectomycorrhizal fungi. Thelephoroids and athelioids are important components of the belowground ectomycorrhizal community in most temperate and boreal forests, but their role might be crucial in forest ecosystems exposed to stress (Peter et al. 2008, Kraigher \& Petkovšek 2011). Their representatives in this study were Tylospora fibrillosa and Amphinema byssoides. Fungal taxa observed by Ostonen et al. (2011) in Norway spruce forests across the European climate gradient were presented in following lineages: "russulalactarius", "tomentella-thelephora", "amphinema-tylospora", "piloderma", "paxillus-gyrodon" and "boletus" as the dominant colonizers most commonly detected in spruce root tips. In our study, members from the groups "russula-lactarius", "tomentella-thelephora" and "amphinema-tylospora" were found as well. However, representatives of "piloderma", /paxillusgyrodon" and "boletus" groups were not recorded during our research. A possible explanation of this difference is that Ostonen et al. (2011) elucidated ectomycorrhizal fungi in Norway spruce stands in different climates, i.e., from subarctic-boreal to temperate regions in Europe.

Baier et al. (2006) investigated the ectomycorrhizal community in upper soil horizons of a young Norway spruce stand in the Bavarian Limestone Alps, which was dominated by Cenococcum geophilum, Tomentella, Lactarius and Sebacina, representing altogether $60 \%$ of all ectomycorrhizal root tips within the plot. All these genera were also recorded at the sites in Serbia examined in this study, although some of them were less abundant.

From 29 ectomycorrhizal anatomorphotypes recorded at the investigated spruce stands in Serbia, 9 types were found on Stara planina, 13 on Kopaonik and 12 types were recorded on Tara mountain.

The lowest number of ectomycorrhizal types was recorded at Stara planina where Picea abies trees are spontaneously occurring in natural beech forest, while Kopaonik and Tara spruce stands were pure or mixed, respectively. Since Norway spruce trees have been naturally grown at these sites for years, more propagules of ecto- mycorrhizal fungi were able to form mycorrhizal symbiosis with spruce trees there. Also, Stara planina has lower altitude, less precipitation and higher temperature than the other two sites.

It is worth noting that there were differences in the age and character of spruce trees in forest stands among the different sites. Namely, the Norway spruce stand on Kopaonik was homogenous and 50 to 70 years old, while the Tara forest stand was comprised of 40- to 50-year-old spruce trees mixed with beech and silver fir, and on Stara planina spruce trees were 10 to 20 years old and planted in natural beech forest. There is a well known division between early- and late-stage fungi that form mycorrhizae with tree roots grown in soils with different physical and chemical properties, especially different accumulations of recalcitrant leaf litter (Last et al. 1987). However, succession is not a process with a strict change of species, but rather species composition complexity is increased with time (Smith \& Read 2008). Similarly, the level of species richness of ectomycorrhizal types correlated with the age of spruce trees at Stara planina.

Investigating the diversity of ectomycorrhizae in four mature spruce stands in Poland, Karlinski \& Kieliszewska-Rokicka (2004) distinguished 37 ectomycorrhizal morphotypes in total. They found relatively high mycorrhizal diversity (28 morphotypes) in the upland mixed forest situated on marsh soil. On the other hand, at the mountain plots with practically homogeneous Norway spruce stands, they recorded only 12 and 13 ectomycorrhizal morphotypes. The number of ectomycorrhizal anatomorphotypes we found at Kopaonik sults. Similarly, in a pure spruce stand on the Taunus mountains in Central Germany, Schirkonyer et al. (2013) recorded 16 mycorrhizal genera and species. On the other hand, sites Kopaonik and Tara differed in forest stand characteristics, namely the spruce forest on Kopaonik was nearly monospecific, while spruce at the Tara site was mixed with Fagus sylvatica and Abies alba. One would expect higher diversity of ectomycorrhizal anatomorphotypes on Tara mountain, but soil conditions and other factors are important as well. Indeed, the influence of plant species diversity and soil conditions on the richness of ectomycorrhizal fungi is well known (Smith \& Read 2008). (13) and Tara (12) is comparable to their re- 
In a 100-year-old Norway spruce forest in Sweden, Dahlberg et al. (1997) identified 25 species of ectomycorrhizal fungi, while in three different forest research plots in Slovenia, Kraigher (1999) recorded 53 ectomycorrhizal types on Norway spruce. Investigating the belowground ectomycorrhizal community in three Norway spruce stands with different degrees of decline in the Czech Republic, Peter et al. (2008) detected 43 ectomycorrhizal types out of which 25, 20 and 15 species were found in the least, moderately and most damaged forest, respectively. The higher number of ectomycorrhizal types in the aforementioned study could be due to the higher number of samples and the longer period of examination.

Dominance of some species in ectomycorrhizal communities is indicated by the Shannon Weaver index (Kraigher \& Petkovšek 2011). The observed values of Shannon Weaver index in the studied sites in Serbia ranged from 0.58 to 1.22 , which was much lower than those obtained in mature spruce stands at unpolluted sites in Slovenia (2.2) and Sweden (3.5), respectively, by Kraigher \& Petkovšek (2011). According to the same authors, this index in polluted areas varied greatly and amounted to 0.2-0.7 in Slovenia and up to 3.3 in France and Denmark (Kraigher \& Petkovšek 2011).

The most abundant ectomycorrhizal types, representing more than $10 \%$ of ectomycorrhizal communities of spruce stands from Stara planina, Kopaonik and Tara were: Laccaria laccata, Russula firmula, $R$. olivacea, Tylospora fibrillosa, Tomentella sp. 1, Tomentella sp. 2, Entoloma sp., Cenococcum sp., Unknown types $\mathrm{K}_{3}$ and $\mathrm{T} 1$; other morphotypes constituted less than $3 \%$ of the entire ectomycorrhizal community. Thus, it is clear that the ectomycorrhizal community associated with spruce from the examined sites in Serbia consisted of few abundant and numerous infrequent ectomycorrhizal types, which is in accordance with previous studies (Karlinski \& Kieliszewska-Rokicka 2004, De Roman \& De Miguel 2005, Katanić et al. 2015).

Wang et al. (2015) investigated the ectomycorrhizal community structure on Picea abies at the tree line in the Austrian Alps; they found that at the higher altitude the ectomycorrhizal community was dominated by Cortinarius sp., whereas at the lower elevation site the community was dominated by Russula. Similarly, we found that in spruce stands in Serbia the genus Russula was the most abundant with four anatomorphotypes, while the genera Clavulina, Tomentella, Inocybe, Sebacina and Cortinarius had two types each.

\section{Root parameters}

The edge of the southernmost distribution of Norway spruce is under constant external pressures, such as pests and unfavourable conditions due to the warming climate (Kapeller et al. 2017). These permanent unfavourable conditions are reflected in the average amount of vital ectomycorrhizal root tips in spruce stands in Serbia that were both in autumn $\left(826-1161 \mathrm{dm}^{-3}\right)$ and spring (1334-2064 $\mathrm{dm}^{-3}$ ) lower than in mature spruce stands in the Central Alps (4309-6716 dm $\mathrm{dm}^{-3}$ - Kraigher 1999).

In this study, the three selected sites did not significantly differ in the number of ectomycorrhizal types and vital ectomycorrhizal root tips nor diversity indices. These results were in accordance with Ostonen et al. (2011), who found no differences between the mean numbers of ectomycorrhizal root tips per spruce tree across the studied gradient. However, total number of fine roots was higher at Stara planina compared to the other two sites.

\section{Comparison of two seasons}

According to previous studies (De Roman \& De Miguel 2005, Katanić et al. 2015), we found no significant differences between the spring and autumn in the number of ectomycorrhizal types and vital ectomycorrhizal root tips, as well as in diversity indices. However, the total number of fine roots was greater in the spring compared with the autumn because of the higher number of old, non-turgescent and nonmycorrhizal roots present in the spring, which could be explained by the seasonal influence on fine roots. Many roots die during winter causing an increase in the number of old and non-turgescent roots in spring. On the other hand, during the growing season, the number of vital roots increases and the senescence of roots decreases, resulting in decreased quantities of old and non-turgescent roots in autumn.

\section{Implication for edible fungi}

Boletus edulis, Cantharellus cibarius and Hydnum rufescens are well-known commercial ectomycorrhizal species (Boa 2004). Based on suitable plant hosts, ecosystem characteristics, and known species from regional etnomycological habits, these fungi were expected to be found in ectomycorrhizae as well. Yet none of the commonly collected edible species were recorded in ectomycorrhizae at the investigated sites, confirming the well-known evidence that above- and below-ground ectomycorrhizal diversity rarely match (Richard et al. 2005).

\section{Exploration types}

Agerer (2001) found a relationship between exploration types and their potential ecological roles, while Rudawska et al. (2011) concluded that the abundance of particular exploration types is related to soil chemistry. Baier et al. (2006) observed that contact- and medium-distance exploration types were associated with soil properties indicative for mineral A-horizon, while short-distance exploration types preferred soil environments rich in humus, which is characteristic for organic layers. Also, they noted that the majority of the ectomycorrhizal fungi preferred organic layers.
In the current study, exploration types characteristic for mineral horizons dominated all tested sites in both seasons. The exception was the short-distance exploration type known to prefer organic layers, which was the most abundant at Tara in the autumn. It is important to highlight that no ectomycorrhizal fungi belonging to long-distance ET were found at all examined sites in both seasons. Abundance of contact- and medium-distance ETs was affected by site. Short-distance ET was present at all sites and the influence of site on its abundance was not statistically significant. Since ectomycorrhizal types belonging to short-distance ET prefer humus-rich environments and its abundance was not influenced by site, it could be assumed that all studied sites have similar characteristics concerning humus content.

\section{Conclusions}

In the first study of ectomycorrhiza on spruce in its southernmost natural distribution area, 29 different types of ectomycorrhizae were identified. The ectomycorrhizal communities investigated at Stara planina, Kopaonik and Tara differed in the composition of ectomycorrhizal types and abundance of contact- and medium-distance exploration types, but not in the mean number of ectomycorrhizal types, number of vital ectomycorrhizal root tips, nor diversity indices. Season had no influence on the parameters assessed nor on the abundance of exploration types. In order to obtain a broader picture of ectomycorrhizal communities in Norway spruce forests in Serbia, further research supplemented with metagenomic approaches should be conducted on more sites.

\section{Acknowledgements}

This work is a part of the project III 43002 "Biosensing technologies and global systems for continuous research and integrated management of ecosystems", financed by the Ministry of Education and Science of the Republic of Serbia, the Research programme $\mathrm{P} 4-0107$ of the Slovenian Research Agency and STSM under COST Action FP1305 for M. Katanić. Dr. Ronald S. Zalesnyis is gratefully acknowledged for revising the manuscript for English style.

\section{References}

Agerer R (1991). Characterization of ectomycorrhiza. In: "Methods in Microbiology, vol. 23" (Norris JR, Read DJ, Varma AK eds). Academic Press, London, UK, pp. 25-72.

Agerer R (2001). Exploration types of ectomycorrhizae. A proposal to classify ECM mycelial systems according to their patterns of differentiation and putative ecological importance. Mycorrhiza 11: 107-114. - doi: 10.1007/s005720100108 Agerer R (2008). Colour atlas of ectomycorrhizae $\left(1^{\text {st }}-13^{\text {th }}\right.$ edn). Einhorn-Verlag Eduard Dietenberger, Schwäbisch Gmünd, Germany.

Agerer R, Danielson RM, Egli S, Ingleby K, Luoma D, Treu R (2006). Descriptions of ectomycor- 
rhizae $\left(1^{\text {st }}-10^{\text {th }}\right.$ edn). Einhorn-Verlag Eduard Dietenberger , Schwäbisch Gmünd, Germany.

Agerer R, Rambold G (2017). DEEMY - An information system for characterization and determination of ectomycorrhizae. Web site. [online] URL: http://www.deemy.de

Atlas R, Bartha R (1981). Introduction to microbiology. Addison-Wesley Publishing Company, Reading, UK, pp. 242-244.

Baier R, Ingenhaag J, Blaschke $\mathrm{H}$, Göttlein A, Agerer R (2006). Vertical distribution of an ectomycorrhizal community in upper soil horizons of a young Norway spruce (Picea abies [L.] Karst.) stand of the Bavarian Limestone Alps. Mycorrhiza 16: 197-206. - doi: 10.1007/s00572006-0035-z

Ballian D, Bogunić F, Božič G (2007). Genetička varijabilnost obične smreke (Picea abies [L.] H. Karst) u bosanskom dijelu Dinarida [Genetic variability of Norway spruce (Picea abies [L.] Karst.) in the Bosnian part of the Dinaric mountain range]. Šumarski List 131: 237-246. [in Slovenian]

Banković S, Medarević M, Pantić D, Petrović N (2009). National Forest Inventory of Republic of Serbia. The growing stock of the Republic of Serbia. Ministry of Agriculture, Forestry and Water Management of the Republic of Serbia Forest Directorate, Belgrade, Serbia, pp. 238.

Bartlett MS (1936). The square root transformation in analysis of variance. Journal of the Royal Statistical Society 3 (suppl): 68-78. - doi: 10.230 7/2983678

Boa E (2004). Wild edible fungi: a global overview of their use and importance to people. Food and Agriculture Organization of the United Nations, Rome, Italy, pp. 147. [online] URL: http://books.google.com/books?id=Zd2NI cNZgvcC

Caudullo G, Tinner W, De Rigo D (2016). Picea abies in Europe: distribution, habitat, usage and threats. In: "European Atlas of Forest Tree Species" (San-Miguel-Ayanz J, De Rigo D, Caudullo G, Houston Durrant T, Mauri A eds). EU Publication Office, Luxembourg, pp. 114-116. [online] URL: http://boris.unibe.ch/80794/

Dahlberg A (2001). Community ecology of ectomycorrhizal fungi: an advancing interdisciplinary field. New Phytologist 150: 555-562. - doi: 10.1046/j.1469-8137.2001.00142.x

Dahlberg A, Jonsson L, Nylund JE (1997). Species diversity and distribution of biomass above and below ground among ectomycorrhizal fungi in an old-growth Norway spruce forest in south Sweden. Canadian Journal of Botany 75: 13231335. - doi: 10.1139/b97-844

De Roman M, De Miguel AM (2005). Post-fire, seasonal and annual dynamics of the ectomycorrhizal community in a Quercus ilex L. forest over a 3-year period. Mycorrhiza 15: 471-482. doi: 10.1007/s00572-005-0353-6

Fernandez C, McCormac L, Hill J, Pritchard S, Koide R (2013). On the persistence of Cenococcum geophilum ectomycorrhizas and its implications for forest carbon and nutrient cycles. Soil Biology and Biochemistry 65: 141-143. - doi: 10.1016/j.soilbio.2013.05.022

Gardes M, Bruns TD (1993). ITS primers with enhanced specificity for basidiomycetes - application to the identification of ectomycorrhizae and rusts. Molecular Ecology 2: 113-118. - doi:
10.1111/j.1365-294X.1993.tboooo5.X Gardes M, Bruns TD (1996). Community structure of ectomycorrhizal fungi in a Pinus muricata forest: above- and below-ground views. Canadian Journal of Botany 74: 1572-1583. - doi: 10.1139/b96-190

Grebenc T, Christensen M, Vilhar U, Cater M, Martin MP, Simončič P, Kraigher H (2009). Response of ectomycorrhizal community structure to gap opening in natural and managed temperate beech-dominated forests. Canadian Journal of Forest Research 39: 1375-1386. - doi: 10.1139/Xo9-072

Jovanović B (1991). Dendrologija [Dendrology]. Naučna knjiga, Beograd, Serbia, pp. 522. [in Serbian]

Kapeller S, Dieckmann U, Schueler S (2017). Varying selection differential throughout the climatic range of Norway spruce in Central Europe. Evolutionary Applications 10: 25-38. - doi: 10.1111/eva.12413

Karlinski L, Kieliszewska-Rokicka B (2004). Diversity of spruce ectomycorrhizal morphotypes in four mature forest stands in Poland. Dendrobiology 51: 25-35. [online] URL: http://yadda.icm. edu.pl/yadda/element/bwmeta1.element.agroarticle-45c624a4-7b82-4d90-9ofa-285adf1c8afo Katanić M, Grebenc T, Orlović S, Matavuly M, Kovačević B, Bajc M, Kraigher H (2015). Ectomycorrhizal fungal community associated with autochthonous white poplar from Serbia. iForest Biogeosciences and Forestry 9: 330-336. - doi: 10.3832/ifor1370-008

Kõljalg U, Nilsson RH, Abarenkov K, Tedersoo L, Taylor AFS, Bahram M, Bates ST, Bruns TT, Bengtsson-Palme J, Callaghan TM, Douglas B, Drenkhan T, Eberhardt U, Dueñas M, Grebenc T, Griffith GW, Hartmann M, Kirk PM, Kohout P, Larsson E, Lindahl BD, Lücking R, Martín MP, Matheny PB, Nguyen NH, Niskanen T, Oja J, Peay KG, Peintner U, Peterson M, Põldmaa K, Saag L, Saar I, Schüler A, Senés C, Smith ME, Suija A, Taylor DE, Telleria MT, Wei M, Larsson $\mathrm{KH}$ (2013). Towards a unified paradigm for sequence-based identification of fungi. Molecular Ecology 22: 5271-5277. - doi: 10.1111/mec.12481 Kraigher H (1996). Tipi mikorize: taksonomija, pomen, aplikacija [Types of ectomycorrhizae their taxonomy, role and application]. Zbornik Gozdarstva in Lesarstva 49: 33-66. [in Slovenian]

Kraigher H (1999). Diversity of types of ectomycorrhizae on Norway spruce in Slovenia. Phyton 39: 199-202. [online] URL: http://www.zobodat. at/pdf/PHY_39_3_0199-0202.pdf

Kraigher H, Petkovšek SA (2011). Mycobioindication of stress in forest ecosystems. In: "Diversity and Biotechnology of Ectomycorrhizae" (Rai M, Varma A eds). Soil Biology Series, vol. 25, Springer, Berlin, Heidelberg, Germany, pp. 301-322. - doi: 10.1007/978-3-642-15196-5_13

Last FT, Dighton J, Mason PA (1987). Successions of sheathing mycorrhizal fungi. Trends in Ecology and Evolution 2: 157-161. - doi: 10.1016/01695347(87)90066-8

Lewandowski A, Burczyk J, Chalupka W (1997). Preliminary results on allozyme diversity and differentiation of Norway spruce (Picea abies (L.) Karst.) in Poland based on plus tree investigations. Acta Societatis Botanicorum Poloniae 66: 197-200. - doi: 10.5586/asbp.1997.025
Mrak T, Gričar J, Kraigher H (2016). Atlas of woody plant roots: morphology and anatomy with special emphasis on fine roots. Studia Forestalia Slovenia 147 ( $1^{\text {st }}$ edn), Slovenian Forestry Institute, The Silva Slovenica Publishing Centre, Ljubljana, Slovenia, pp. 118.

NCBI (2017). GenBank. Web site. [online] URL: http://www.ncbi.nlm.nih.gov/genbank/index.ht $\mathrm{ml}$

Ostonen I, Helmisaari H-S, Borken W, Tedersoo L, Kukumägi $M$, Bahram $M$, Lindroos A-J, Nöjd P, Uri V, Merilä P, Asi E, Lohmus K (2011). Fine root foraging strategies in Norway spruce forests across a European climate gradient. Global Change Biology 17: 3620-3632. - doi: 10.1111/j.1365-2486.2011.02501.x

Ostonen I, Rosenvald K, Helmisaari H-S, Godbold D, Parts K, Uri V, Lohmus K (2013). Morphological plasticity of ectomycorrhizal short roots in Betula sp. and Picea abies forests across climate and forest succession gradients: its role in changing environments. Frontiers in Plant Science 4: 1-10. - doi: 10.3389/fpls.2013.00335

Peter M, Ayer F, Cudlin P, Simon E (2008). Belowground ectomycorrhizal communities in three Norway spruce stands with different degrees of decline in the Czech Republic. Mycorrhiza 18: 157-169. - doi: 10.1007/s00572-008-016 6-5

Ravazzi C (2002). Late Quaternary history of spruce in southern Europe. Review of Palaeobotany and Palynology 120: 131-177. - doi: 10.1016/ S0034-6667(01)00149-X

RSHS (2017). Home page. Republic of Serbia - Hydrometeorological Service (RSHS), Web site. [online] URL: http://www.hidmet.gov.rs/index_ lat.php

Richard F, Millot S, Gardes M, Selosse M-A (2005). Diversity and specificity of ectomycorrhizal fungi retrieved from an old-growth Mediterranean forest dominated by Quercus ilex. New Phytologist 166: 1011-1023. - doi: 10.1111 /j.1469-8137.2005.01382.x

Rudawska M, Leski T, Stasinska M (2011). Species and functional diversity of ectomycorrhizal fungal communities on Scots pine (Pinus sylvestris L.) trees on three different sites. Annals of Forest Science 68: 5-15. - doi: 10.1007/s13595-0100002-x

Schirkonyer U, Bauer C, Rothe G (2013). Ectomycorrhizal diversity at five different tree species in forests of the Taunus Mountains in Central Germany. Open Journal of Ecology 3: 66-81. doi: 10.4236/oje.2013.31009

Skrøppa T (2003). EUFORGEN technical guidelines for genetic conservation and use for Norway spruce (Picea abies). International Plant Genetic Resources Institute (IPGRI), Rome, Italy, pp. 6. [online] URL: http://books.google. com/books?id=hrNlgKNYZEcC

Smith SE, Read DJ (2008). Mycorrhizal symbiosis ( $3^{\text {rd }}$ edn). Elsevier-Academic Press, London, UK, pp. 787.

Snedecor W, Cochran WG (1976). Statistical methods ( $6^{\text {th }}$ edn). The lowa State University Press, Ames, lowa, USA, pp. 503.

Sulzbacher MA, Grebenc T, García MA, Silva BD, Silveira A, Antoniolli ZI, Marinho P, Münzenberger B, Telleria MT, Baseia IG, Martín MP (2016). Molecular and morphological analyses confirm Rhizopogon verii as a widely distributed 
ectomycorrhizal false truffle in Europe, and its presence in South America. Mycorrhiza 26: 377388. - doi: 10.1007/s00572-015-0678-8

Taylor AFS, Martin F, Read DJ (2000). Fungal diversity in ectomyccorhizal communities of Norway spruce (Picea abies (L.) Karst.) and beech (Fagus sylvatica L.) along north-south transects in Europe. In: "Carbon and Nitrogen Cycling in European Forest Ecosystems” (Schulze E-D ed).
Ecological Studies 142, Springer-Verlag, Berlin, Heidelberg, Germany, pp. 343-365.

Wang L, Burenjargal O, Godbold D (2015). Ectomycorrhizal and soil enzyme activity profiles at the tree line. Meeting of COST Action FP1305 BioLink: Linking soil biodiversity and ecosystem function in European forests "Belowground biodiversity in changing environment". JagielIonian University, Kraków, Poland, pp. 25.
White TJ, Bruns T, Lee S, Taylor J (1990). Amplification and direct sequencing of fungal ribosomal RNA genes for phylogenetics. In: "PCR Protocols. A guide to methods and applications" (Innis MA, Gelfand DH, Sninsky JJ, White TJ eds). Academic Press, San Diego, CA, USA, pp. 315-322. - doi: 10.1016/B978-0-12-372180-8.50042- 